\title{
IDENTIFIKASI JENIS ATTENTION DEFICIT HYPERACTIVITY DISORDER (ADHD) PADA ANAK USIA DINI MENGGUNAKAN METODE NEIGHBOR WEIGHTED K-NEAREST NEIGHBOR (NWKNN)
}

\author{
Putri Nur Fadila ${ }^{1}$,S.Kom, Indriati,S.T.,M.Kom ${ }^{2,}$ Dian Eka Ratnawati,S.Si,M.Kom ${ }^{3}$ \\ 1) Teknik Informatika, Fakultas Ilmu Komputer, Universitas Brawijaya \\ 2) Teknik Informatika, Fakultas Ilmu Komputer, Universitas Brawijaya \\ 3) Teknik Informatika, Fakultas Ilmu Komputer, Universitas Brawijaya
}

Email: fadilaputrifadila@gmail.com, indriati.tif@ub.ac.id, dian_ilkom@ub.ac.id

(Naskah masuk: 8 Agustus 2016, diterima untuk diterbitkan: 8 September 2016)

\begin{abstract}
Abstrak
Fase pertumbuhan dan perkembangan merupakan fase terpenting pada manusia, khususnya pada anak usia dini. Pertumbuhan dan perkembangan pada anak mempengaruhi bagaimana seorang anak tersebut ketika mencapai dewasa baik dari segi mental, fisik, maupun kecerdasaannya. Tentunya tidak semua anak mengalami perkembangan yang normal, bisa saja ada yang mengalami gangguan perkembangan. Salah satu gangguan perkembangan yang sering dialami pada anak usia dini adalah ADHD (Attention Deficit Hyperactivity Disorder). Untuk ADHD sendiri terdapat tiga jenis yaitu Inattention, Impulsif, dan Hyperactivity. Pada penelitian ini akan dilakukan identifikasi jenis ADHD berdasarkan gejala yang muncul menggunakan metode klasifikasi Neighbor Weigted K-Nearest Neighbor (NWKNN). Metode NWKNN merupakan metode perkembangan dari metode KNN, yang membedakan adalah pada NWKNN terdapat proses pembobotan terhadap setiap jenis yang akan di klasifikasikan. Pada penelitian ini akan dilakukan identifikasi jenis yang terdiri atas 4 jenis meliputi Inattention, Impulsif, Hyperactivity, dan Tidak ADHD. Hasil dari penelitian ini menunjukkan bahwa metode NWKNN dapat melakukan identifikasi jenis ADHD dengan baik ketika data latih yang digunakan sebanyak 80 data dengan data uji sebanyak 20 data, nilai $K=10$, dan nilai $E=4$ dengan hasil akurasinya mencapai 95\%. Pada penelitian ini juga membuktikan bahwa metode NWKNN memiliki rata-rata akurasi $2 \%$ lebih baik dibandingkan metode KNN dalam melakukan identifikasi jenis ADHD
\end{abstract}

Kata Kunci: Perkembangan, Anak Usia Dini, ADHD, dan Metode NWKNN

\begin{abstract}
Growth and development are the most important fase for human, especially for early age children. Growth and development indeed give an influence on how the child in mentalism, physical and shrewdness aspect when they are getting older. Not every children has a normal development, some of them can have development disruption. One of development disruptions that happen often for early age children is ADHD (Attention Deficit Hyperactivity Disorder). For ADHD, it has three kinds, which are inattention, impulsif and hyperactivity. In this research, the researcher will detect the kind of ADHD based on symptom arise using Neighbor Weigted K-Nearest Neighbor (NWKNN) method. NWKNN method is one of development methods from KNN method, the different is on NWKNN there is integrity process on every kind which being classified. In this research, there will be done some identification kind which consist of 4 kinds, Inattention, Implusif, Hyperactivity and not ADHD. The result of this research shows that NWKNN method able to done the ADHD identification well when data consist of 80 data training, 20 data testing, $K$ score $=10$, and E score $=4$ with accuracy result that reach $95 \%$. In this research also prove that NWKNN method have an accuracy of $2 \%$ better than KNN method to detect kind of ADHD.
\end{abstract}

Keywords: Development, Early Age Children, ADHD, and NWKNN Method

\section{PENDAHULUAN}

Setiap manusia yang telah terlahir ke dunia pasti mengalami fase pertumbuhan dan perkembangan. Perubahan secara fisiologi pada jangka waktu tertentu pada anak disebut dengan pertumbuhan, sedangkan perkembangan merupakan proses penyempurnaan fungsi sosial dan psikologis dengan kangka waktu yang berlangsung sepanjang hidup (Ikalor,2013). Fase usia yang selalu menjadi sorotan dan perhatian orang tua adalah fase ketika anak berada di usia dini. Seorang anak dikatakan berada pada usia dini ketika mereka berada di rentan usia 0-8 tahun (Habibi, 2015) dan fase tersebut bisa disebut sebagai golden age. Pada fase pertumbuhan 
dan perkembangan dapat juga disimpulkan bahwasannya orang tua tidak begitu memahami pertumbuhan dan perkembangan anaknya tersebut normal atau tidak. Hal itu bisa saja terjadi karena orang tua terlalu senang ketika sang buah hati tumbuh dan berkembang dengan cepat karena setiap tingkah lakunya yang menggemaskan dan lucu, atau bisa jadi orang tua menganggap biasa saja ketika tumbuh dan berkembangnya sang buah hati terkesan lambat karena menganggap belum waktunya belum saatnya (Limbong,2015).

Salah satu perilaku yang tidak normal atau bisa disebut dengan perilaku abnormal disebut dengan ADHD. ADHD merupakan singkatan dari AttentionDefict/Hyperactivity Disorder merupakan gangguan motorik yang bisa membuat seseorang sulit dalam memperhatikan atau konsentrasi dan berperilaku yang berlebihan (Aini,2013).

Pada umumnya yang lebih banyak teridentifikasi terkena ADHD adalah laki-laki dibandingkan perempuan dengan rasio 2:1 pada anak kecil dan 1,6 : 1 pada orang dewasa, dan berdasarkan hasil survei populasi ditunjukkan bahwa ADHD 5\% terjadi pada anak kecil dan 2,5\% pada orang dewasa (DSM V, 2013). Selain itu menurut SV Faraone dkk, 2003 dan JB Schweitzer dkk, 2012 serta J.Biederman, 2005 yang disampaikan oleh Luz Bar ona-Lleo dkk, 2016 dalam jurnalnya bahwa ADHD diperkirakan 5-10\% mempengaruhi anak usia sekolah dan 3-5\% mempengaruhi orang dewasa berdasarkan kriteria diagnostik yang digunakan (Barona-Lleo et al,2015).

Seperti yang disampaikan sebelumnya, karena kurangnya pemahaman orang tua bisa jadi seorang anak mengalami perilaku yang abnormal, salah satunya adalah ADHD. Atau orang tua telah menyadari bahwa anaknya mengalami ADHD namun tidak mengetahui secara pasti jenis ADHD yang diderita sang anak.

Terdapat 3 jenis ADHD yakni Inattention, Impulsif, dan Hyperactivity. Pada penelitian ini akan dilakukan identifikasi jenis ADHD pada anak usia dini dengan melakukan proses perhitungan berdasarkan gejala yang muncul. Jenis yang diidentifikasi atau diklasifikasin bukan hanya 3 jenis tersebut melainkan juga terdapat jenis yang tergolong Tidak ADHD. Data yang digunakan pada penelitian ini bersifat data tidak seimbang, karena jumlah sebaran setiap jenis tidak merata sehingga terlihat adanya kelas mayoritas dan kelas minoritas.

Pemecahan masalah untuk data yang tidak seimbang, seperti halnya data untuk identifikasi ADHD ini, bisa menggunakan metode Neighbor Weighted K-Nearest Neighbor (NWKNN) yang dikenalkan oleh Sangbo Tan pada tahun 2005 melalui penelitiannya terkait corpus berbahasa Inggris dan berbasa Mandarin (Arissaputra, 2015).

Berdasarkan beberapa permasalahan yang telah disebutkan, maka penulis mengusulkan penelitian dengan judul "Identifikasi Jenis Attention Deficit Hyperactivty Disorder (ADHD) pada Anak Usia Dini menggunakan Metode Neighbor Weighted K-Nearest Neighbor (NWKNN)",

\section{METODE}

\subsection{Langkah Penelitian}

Sumber yang digunakan dalam penelitian ini berasal dari House Of Fatima. House Of Fatima merupakan salah satu tempat terapi untuk anak berkebutuhan khusus baik dari segi pertumbuhan maupun perkembangannya yang berlokasikan di $\mathrm{Jl}$. Sumbing No.10 Kota Malang.

Langkah-langkah yang dilakukan dalam penelitian ini adalah :

1. Mengumpulkan data hasil kuisioner yang diperoleh dari House of Fatima untuk digunakan sebagai data latih

2. Menjawab setiap penyataan yang ada pada kuisioner pada sistem sebagai data uji

3. Melakukan identifikasi menggunakan metode Neighbor Weighted K-Nearest Neighbor (NWKNN)

4. Melakukan analisis terhadap hasil identifikasi yang dihasilkan sistem dengan melakukan pengujian akurasi.

\subsection{Deskripsi Data}

Data yang digunakan baik data uji maupun data latih berasal dari hasil kuisioner yang terdiri atas 45 pernyataan gejala dengan 4 alternatif pilihan jawaban yang mempunyai bobot berbeda-beda. Sebagai contoh data dan bobot yang digunakan dapat dilihat pada tabel 1 .

Tabel 1. Data Gejala dan pembobotannya

\begin{tabular}{|c|c|c|c|c|}
\hline No & Kode & Gejala & Opsi & Nilai \\
\hline \multirow{3}{*}{1} & \multirow{3}{*}{ G01 } & \multirow{3}{*}{$\begin{array}{c}\text { Ananda kurang } \\
\text { memperhatikan } \\
\text { benda yang } \\
\text { ditunjukkan }\end{array}$} & Selalu & 50 \\
\hline & & & $\begin{array}{l}\text { Kadang- } \\
\text { Kadang }\end{array}$ & 35 \\
\hline & & & $\begin{array}{l}\text { Tidak } \\
\text { pernah }\end{array}$ & 15 \\
\hline 2 & G02 & $\begin{array}{l}\text { Ananda mudah } \\
\text { mengalihkan } \\
\text { pandangan pada }\end{array}$ & Selalu & 50 \\
\hline
\end{tabular}




\begin{tabular}{|c|c|c|c|c|}
\hline & & $\begin{array}{l}\text { sesuatu ketika } \\
\text { dalam } \\
\text { pembicaraan } \\
\text { (masih terjadi } \\
\text { kontak mata) }\end{array}$ & $\begin{array}{l}\text { Kadang- } \\
\text { Kadang }\end{array}$ & 35 \\
\hline & & & $\begin{array}{l}\text { Tidak } \\
\text { pernah }\end{array}$ & 15 \\
\hline \multirow{3}{*}{45} & \multirow{3}{*}{ G45 } & \multirow{3}{*}{$\begin{array}{c}\text { Ananda tampak } \\
\text { terburu-buru } \\
\text { dalam } \\
\text { beraktifitas }\end{array}$} & Selalu & 50 \\
\hline & & & $\begin{array}{l}\text { Kadang- } \\
\text { Kadang }\end{array}$ & 35 \\
\hline & & & $\begin{array}{l}\text { Tidak } \\
\text { pernah }\end{array}$ & 15 \\
\hline
\end{tabular}

\subsection{Diagram Blok Sistem}

Diagram blok sistem merupakan diagram yang berbentuk blok-blok yang menggambarkan aliran proses yang menjelaskan cara kerja sistem secara terstruktur. Diagram blok sistem akan disajikan pada gambar 1.

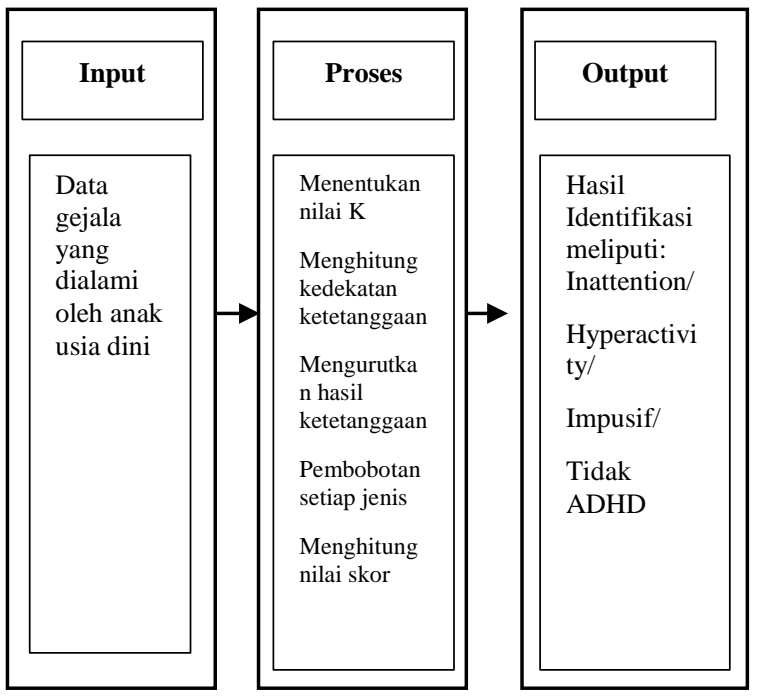

Gambar 1 Diagram Blok Proses Identifikasi Jenis ADHD pada Anak Usia Dini menggunakan Metode NWKNN

pada gambar 1 menjelaskan diagram blok yang mewakili beberapa komponen sistem identifikasi jenis ADHD dengan menggunakan metode NWKNN yang akan dibangun mulai dari proses input hingga output yang dihasilkan.

\subsection{Metode KNN}

KNN (K-Nearest Neighbor) merupakan salah satu metode klasifikasi yang didasarkan atas kedekatan ketetanggan nilai kelas, klasifikasi dilakukan berdasarkan kesamaan atau jarak yang telah disimpan pada data latih (Adeniyi et all, 2016). Menurut D.A Adeniyi et al (2016) dan Valerian (2015) langkah pada algoritma KNN diawali dengan menentukan nilai parameter $\mathrm{K}$ kemudian menghitung nilai kedekatan ketetanggaan antara data uji dengan data latih dengan menggunakan persamaan Euclidean Distance atau Cosine Similiraty (CosSim).

Perhitungan Euclidean Distance dapat diformulasikan pada persamaan

$$
d\left(x_{1}, x_{2}\right)=\sqrt{\sum_{i=1}^{n}\left(x_{2 i}-x_{1 i}\right)^{2}}
$$

Dimana :

$\mathrm{X}_{1}$ : nilai dari tiap data latih

$\mathrm{X}_{2}$ : nilai dari tiap data uji

$\mathrm{n}$ : banyaknya data

i : data ke-i

Sedangkan untuk perhitungan CosSim dapat diformulasikan pada persamaan

$$
\operatorname{Cos} \operatorname{Sim}\left(q, d_{j}\right)=\frac{\vec{d}_{j} \bullet \vec{q}}{\left|\vec{d}_{j}\right| \bullet|\vec{q}|}=\frac{\sum_{i=1}^{m}\left(w_{i j} \bullet w_{i q}\right)}{\sqrt{\sum_{i=1}^{m} w_{i j}^{2} \bullet \sum_{i=1}^{m} w_{i q}^{2}}}
$$

Dimana :

$\operatorname{Cos} \operatorname{Sim}\left(X, d_{i}\right):$ nilai $\operatorname{Cos} \operatorname{Sim}$, similiritas data uji X

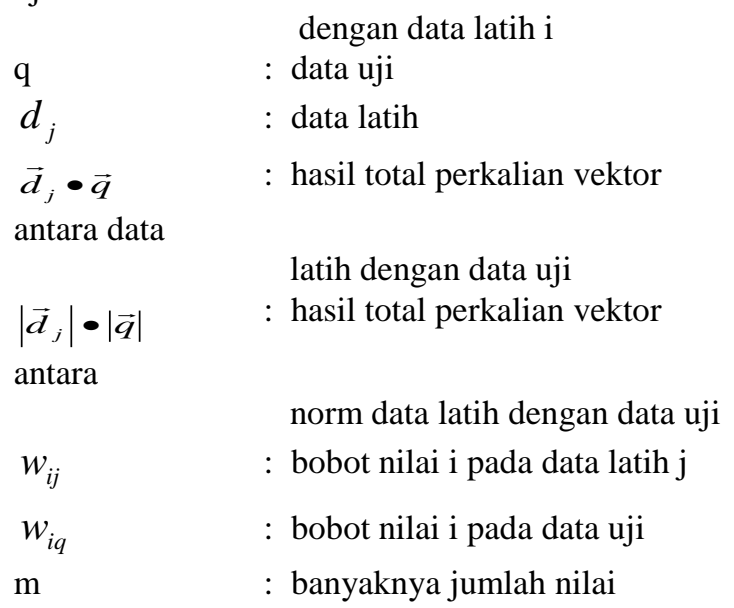

Setelah didapatkan hasil kedekatan ketetanggan, kemudian dilakukan pengurutan hasil Euclidean Distance dari hasil terkecil ke terbesar atau mengurutkan hasil CosSim dari terbesar ke terkecil. Ketika telah didapatkan hasil $\mathrm{K}$ tetangga terdekat dari hasil penurutan tersebut maka dihitung nilai skornya berdasarkan nilai yang ada, perhitungan skor tersebut dapat di formulasikan kedalam persamaan 
$\operatorname{Score}\left(X, C_{i}\right)=\sum_{d j K N N(X)}\left(\left(\sqrt{\sum_{i=1}^{n}\left(x_{2 i}-x_{1 i}\right)^{2}}\right) * \delta\left(d_{j}, C_{i}\right)\right)$

atau

$\operatorname{Score}\left(X, C_{i}\right)=\sum_{d j K N N(X)}\left(\left(\operatorname{Sim}\left(q, d_{j}\right) * \delta\left(d_{j}, C_{i}\right)\right)\right.$

(4)

Dimana :

$\operatorname{djKNN}(x) \quad$ : data latih $d_{j}$ pada kumpulan tetangga

terdekat dari data uji X

$\sqrt{\sum_{i=1}^{n}\left(x_{2 i}-x_{1 i}\right)^{2}}:$ jarak antara data uji dan data latih

$\delta\left(d_{j}, C_{i}\right) \quad$ : akan bernilai 1 jika nilai jarak $\in$

$\mathrm{C}_{\mathrm{i}}$ dan

bernilai 0 jika nilai jarak $\notin \mathrm{C}_{\mathrm{i}}$

$\mathrm{C}_{\mathrm{i}}$

$\operatorname{Sim}\left(\mathrm{q}, \mathrm{d}_{\mathrm{j}}\right) \quad$ : nilai $\operatorname{Cos} \operatorname{Sim}$ antara data uji dan data

latih.

\subsection{Metode NWKNN}

Metode NWKNN merupakan metode yang hampir mirip dengan metode KNN. Metode NWKNN muncul karena adanya permasalahan data tidak seimbang pada data latih. Yang membedakan antara metode NWKNN dengan metode KNN adalah adanya pemberian bobot pada kelas/jenis yang berasal dari kategori mayoritas maka diberi nilai bobot kecil, sedangkan pada kategori minoritas akan diberi nilai bobot besar (Ridok dkk,2015).

Langkah algoritma pada metode NWKNN tidak jauh berbeda dengan langkah algoritma KNN, yang membedakan adalah perhitungan bobot dan score untuk menentukan klasifikasi terhadap data uji (Feizar, 2014).

Perhitungan bobot dapat dilakukan dengan persamaan :

$$
\text { Weight }_{i}=\frac{1}{\left(\frac{\operatorname{Num}\left(C_{i}^{d}\right)}{\operatorname{Min}\left\{\operatorname{Num}\left(C_{n}^{d}\right) \mid n=1, \ldots, K^{*}\right\}}\right)^{1 / \exp }}
$$

Dimana

$$
\begin{aligned}
& \operatorname{Num}\left(C_{i}^{d}\right)=\text { banyaknya data latih } d \text { pada } \\
& \operatorname{Num}\left(C_{j}^{d}\right)=\text { banyaknya data latih } d \text { pada } \\
& \operatorname{Exp} \quad=\text { Eksponen (nilai exp lebih dari 1) }
\end{aligned}
$$

Setiap nilai bobot yang didapatkan akan digunakan untuk menghitung nilai skor data uji terhadap setiap kelas/jenis. Perhitungan score pada metode NWKNN dapat dilakukan dengan persamaan :
$\operatorname{Score}\left(X, C_{i}\right)=$ Weight $_{\mathrm{i}} *\left(\sum_{d j K N N(X)}\left(\left(\sqrt{\sum_{i=1}^{n}\left(x_{2 i}-x_{1 i}\right)^{2}}\right) * \delta\left(d_{j}, C_{i}\right)\right)\right)$

(6)

Atau

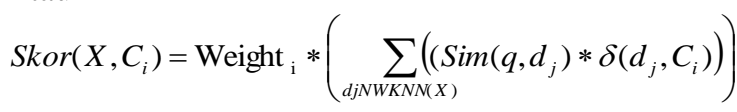

Dimana:

Weight $_{\mathrm{i}} \quad$ : Bobot jenis/kelas i

djNWKNN(x) : data latih $d_{j}$ pada kumpulan tetangga

terdekat dari data uji X

$\sqrt{\sum_{i=1}^{n}\left(x_{2 i}-x_{1 i}\right)^{2}}:$ jarak antara data uji dan data latih

$\delta\left(d_{j}, C_{i}\right) \quad$ : akan bernilai 1 jika nilai jarak $\in \mathrm{C}_{\mathrm{i}}$

$\operatorname{Sim}\left(\mathrm{q}, \mathrm{d}_{\mathrm{j}}\right) \quad$ : nilai CosSim antara data uji dan data

$\mathrm{C}_{\mathrm{i}} \quad$ : jenis atau kelas $\mathrm{i}$

\section{HASIL DAN PEMBAHASAN}

Pada bagian ini akan dibahas terkait pengujian dan analisis yang dilakukan terhadap sistem. Pengujian yang dilakukan adalah pengujian akurasi, pengujian akurasi dilakukan untuk mengetahui seberapa besar kevalidan identifikasi dengan menggunakan metode NWKNN. Pengujian dilakukan dengan cara menghitung nilai kebenaran setiap melakukan pengujian pada data.

\subsection{Pengujian dan Analisis Pengaruh Perubahan Nilai K}

\begin{tabular}{|c|c|c|c|c|c|}
\hline \multirow{2}{*}{$\begin{array}{c}\text { Jumlah } \\
\text { Data } \\
\text { Uji }\end{array}$} & \multirow{2}{*}{$\begin{array}{c}\text { Nilai } \\
\text { E }\end{array}$} & \multirow{2}{*}{$\begin{array}{c}\text { Nilai } \\
\mathrm{K}\end{array}$} & \multicolumn{3}{|c|}{$\begin{array}{c}\text { Akurasi Untuk Data Latih } \\
(\%)\end{array}$} \\
\hline & & & 80 data & 70 data & $\begin{array}{c}60 \\
\text { data }\end{array}$ \\
\hline \multirow{9}{*}{20} & \multirow{9}{*}{4} & 2 & $80 \%$ & $80 \%$ & $70 \%$ \\
\hline & & 4 & $85 \%$ & $85 \%$ & $75 \%$ \\
\hline & & 8 & $90 \%$ & $80 \%$ & $65 \%$ \\
\hline & & 10 & $95 \%$ & $90 \%$ & $70 \%$ \\
\hline & & 15 & $80 \%$ & $90 \%$ & $55 \%$ \\
\hline & & 20 & $85 \%$ & $80 \%$ & $65 \%$ \\
\hline & & 25 & $75 \%$ & $70 \%$ & $65 \%$ \\
\hline & & 30 & $75 \%$ & $65 \%$ & $50 \%$ \\
\hline & & 35 & $60 \%$ & $50 \%$ & $45 \%$ \\
\hline
\end{tabular}

Pengujian ini dilakukan dengan mengubah nilai $\mathrm{K}$ secara acak dengan nilai 2, 4, 8, 10, 15, 20, 25, 30, 35 , dan 40 . Hasil pengujian pengaruh nilai $\mathrm{K}$ dapat dilihat pada tabel 2 berikut ini.

Tabel 2. Hasil Pengujian Pengaruh Nilai K 


\begin{tabular}{|l|l|l|l|l|}
\hline & $\mathbf{4 0}$ & $\mathbf{5 0 \%}$ & $\mathbf{4 5 \%}$ & $\mathbf{4 5 \%}$ \\
\hline
\end{tabular}

Berdasarkan tabel hasil pengujian pengaruh nilai $\mathrm{K}$ didapatkan hasil hubungan antara perubahan nilai $\mathrm{K}$ dengan akurasi yang dihasilkan untuk identifikasi jenis ADHD dengan menggunkana metode NWKNN. Hasil akurasi yang dihasilkan cenderung tidak stabil akan tetapi hasil akurasi terbaik dihasilkan saat $\mathrm{K}=10$, setelah $\mathrm{K}=10$ dan nilai $\mathrm{K}$ semakin besar hasil akurasi cenderung menurun. Penurunan hasil akurasi terjadi karena ketika semakin besarnya nilai $\mathrm{K}$ tetangga yang digunakan maka semakin banyak data yang mempunyai jumlah jenis yang mendominasi masuk kedalam ketetanggaan yang telah ditentukan. Sehingga ketika dilakukan deteksi, data uji akan sering masuk kedalam jenis yang salah. Pada deteksi ADHD menggunakan metode NWKNN ini, data yang ada lebih didominasi dengan Tidak ADHD, sehingga ketika di lakukan proses deteksi dengan metode NWKNN, Tidak ADHD yang paling sering muncul dan dituju bila terjadi kesalahan deteksi.

\subsection{Pengujian dan Analisis Perubahan Nilai E}

Pengujian ini dilakukan dengan mengubah nilai E secara acak dimulai dari $\mathrm{E}=2, \mathrm{E}=4, \mathrm{E}=8$ dan $\mathrm{E}=$ 16. Perubahan nilai $\mathrm{E}$ ini dilakukan pada metode NWKNN dengan menggunakan Euiclidean Distance.

Hasil pengujian pengaruh nilai E dapat dilihat pada tabel 3 berikut ini.

Tabel 3. Hasil Pengujian Pengaruh Nilai E

\begin{tabular}{|c|c|c|c|c|c|}
\hline \multirow{2}{*}{$\begin{array}{c}\text { Jumlah } \\
\text { Data } \\
\text { Uji }\end{array}$} & \multirow{2}{*}{$\begin{array}{c}\text { Nilai } \\
\text { K }\end{array}$} & \multirow{2}{*}{$\begin{array}{c}\text { Nilai } \\
\text { E }\end{array}$} & \multicolumn{3}{|c|}{$\begin{array}{c}\text { Akurasi Untuk Data } \\
\text { Latih (\%) }\end{array}$} \\
\hline \multirow{3}{*}{20} & & $\begin{array}{c}80 \\
\text { data }\end{array}$ & $\begin{array}{c}70 \\
\text { data }\end{array}$ & $\begin{array}{c}60 \\
\text { data }\end{array}$ \\
\hline \multirow{3}{*}{20} & & 2 & $85 \%$ & $80 \%$ & $60 \%$ \\
\cline { 3 - 6 } & \multirow{2}{*}{10} & 4 & $95 \%$ & $90 \%$ & $70 \%$ \\
\cline { 3 - 6 } & & 8 & $95 \%$ & $80 \%$ & $70 \%$ \\
\cline { 3 - 6 } & & 16 & $90 \%$ & $80 \%$ & $70 \%$ \\
\hline
\end{tabular}

terlihat bahwa perubahan nilai E pada pengujian cenderung memberikan hasil yang stabil dan sama terhadap hasil akurasi pada beberapa nilai E, walaupun data latih yang digunakan berbeda-beda pada varian nilai E. Hal ini menunjukkan bahwa perubahan nilai $E$ tidak begitu memberikan pengaruh yang besar terhadap lebih baik atau buruknya hasil akurasi pada identifikasi jenis ADHD pada sistem.

\subsection{Pengujian dan Analisis Perubahan Jumlah Data Latih}

Pengujian pengaruh perubahan jumlah data latih dilakukan sebanyak tiga kali. Data latih yang digunakan bersifat tidak seimbang disetiap kelasnya
(Tidak ADHD, Inattentiom, Impulsif, dan Hyperactivity). Pengujian dilakukan dengan cara mengetahui hasil akurasi pada saat jumlah data uji sebanyak 20 data dengan data latih sebanyak 80 data, 70 data dan 60 data. Hasil pengujian pengaruh jumlah data latih dapat dilihat pada tabel 4 berikut ini.

Tabel 4. Pengaruh Perubahan Jumlah Data Latih

\begin{tabular}{|c|c|c|c|c|}
\hline \multirow{2}{*}{$\begin{array}{c}\text { Jumlah Data } \\
\text { Uji }\end{array}$} & $\begin{array}{c}\text { Nilai } \\
\mathrm{K}\end{array}$ & $\begin{array}{c}\text { Nilai } \\
\mathrm{E}\end{array}$ & $\begin{array}{c}\text { Jumlah } \\
\text { Data } \\
\text { Latih }\end{array}$ & Akurasi \\
\hline \multirow{2}{*}{20} & \multirow{2}{*}{10} & \multirow{2}{*}{4} & 80 & $95 \%$ \\
\cline { 4 - 5 } & & & 70 & $90 \%$ \\
\cline { 4 - 5 } & &
\end{tabular}

Berdasarkan tabel terlihat bahwa hasil akurasi yang diperoleh pada pengujian ini bervariasi. Semakin banyak jumlah data yang digunakan pada data latih, akurasi yang diperoleh juga semakin meningkat. Hal ini disebabkan ketika semakin banyak data latih yang digunakan maka akan semakin banyak data yang akan dibandingkan dengan data uji dan memungkinkan untuk memperoleh hasil CosSim yang mempunyai similarity yang mendekati data uji yang akan diidentifikasi cenderung tinggi untuk masuk kedalam ketetangaannya.

\subsection{Pengujian dan Analisis Perbandingan Akurasi antara metode NWKNN dan KNN}

Pengujian dilakukan dengan membandingan hasil akurasi antara metode KNN dengan metode NWKNN. Perbandingan hasil akurasi tersebut dilakukan dengan melihat selisih hasil akurasi yang diperoleh antara metode KNN dengan metode NWKNN. Pengujian dilakukan dengan menggunakan data latih sejumlah 80 data dan data uji sebanyak 20 data. Hasil pengujian perbandingan akurasi metode NWKNN dan KNN dapat dilihat pada tabel 5 berikut ini.

Tabel 5. Perbandingan KNN dan NWKNN

\begin{tabular}{|c|c|c|c|c|}
\hline $\begin{array}{c}\text { Jumlah } \\
\text { Data Uji }\end{array}$ & $\begin{array}{c}\text { Jumlah } \\
\text { Data } \\
\text { Latih }\end{array}$ & $\begin{array}{c}\text { Nilai } \\
\mathrm{K}\end{array}$ & KNN & NWKNN \\
\hline \multirow{10}{*}{20} & \multirow{10}{*}{80} & 2 & $80 \%$ & $80 \%$ \\
\hline & & 4 & $85 \%$ & $85 \%$ \\
\hline & & 8 & $95 \%$ & $90 \%$ \\
\hline & & 10 & $95 \%$ & $95 \%$ \\
\hline & & 15 & $95 \%$ & $80 \%$ \\
\hline & & 20 & $90 \%$ & $85 \%$ \\
\hline & & 25 & $70 \%$ & $75 \%$ \\
\hline & & 30 & $50 \%$ & $75 \%$ \\
\hline & & 35 & $55 \%$ & $60 \%$ \\
\hline & & 40 & $45 \%$ & $50 \%$ \\
\hline \multicolumn{3}{|c|}{ Hasil Rata-Rata Akurasi } & $76 \%$ & $78 \%$ \\
\hline
\end{tabular}


Pada tabel tersebut terlihat bahwasanya metode NWKNN cenderung menghasilkan hasil akurasi yang lebih baik dibandingan dengan metode KNN khususnya pada saat $\mathrm{K}$ besar untuk kasus identifikasi jenis ADHD dengan data latih yang digunakan tidak seimbang. Hal tersebut dikarenakan pada NWKNN terdapat proses pembobotan yang dapat membantu data uji yang berasal dari kelas minoritas dapat dikenali dan teridentifikasi kedalam jenis yang tepat. Oleh karena itu, dapat dikatakan bahwa pada kasus identifikasi jenis ADHD ini lebih baik menggunakan metode NWKNN dibandingkan metode KNN dengan hasil metode NWKNN lebih baik 2\% ratarata hasil akurasinya.

3.5. Pengujian dan Analisis Perbandingan Hasil Akurasi antara NWKNN dengan menggunakan Euclidean Distance dan CosSim

Pengujian dilakukan dengan membandingan hasil akurasi antara metode NWKNN dengan menggunakan Euclidean Distance atau CosSim untuk mengetahui kedekatan ketetanggaan antara data uji dan data latihnya. Hasil pengujian perbandingan akurasi metode NWKNN menggunakan Euclidean Distance dan CosSim dapat dilihat pada tabel 6 berikut ini.

Tabel 6. Perbandingan Akurasi Metode NWKNN menggunakan Euclidean Distance dan CosSim.

\begin{tabular}{|c|c|c|c|c|c|}
\hline \multirow[b]{2}{*}{$\begin{array}{c}\text { Jumla } \\
\text { h Data } \\
\text { Uji }\end{array}$} & \multirow[b]{2}{*}{$\begin{array}{c}\text { Jumla } \\
\text { h Data } \\
\text { Latih }\end{array}$} & \multirow[b]{2}{*}{$\begin{array}{c}\text { Nilai } \\
\mathrm{E}\end{array}$} & \multirow[b]{2}{*}{$\begin{array}{c}\text { Nilai } \\
\mathrm{K}\end{array}$} & \multicolumn{2}{|c|}{ NWKNN dengan } \\
\hline & & & & $\begin{array}{c}\text { Euiclidea } \\
\mathrm{n} \\
\text { Distance }\end{array}$ & Cossim \\
\hline \multirow{10}{*}{20} & \multirow{10}{*}{80} & \multirow{10}{*}{4} & 2 & $90 \%$ & $80 \%$ \\
\hline & & & 4 & $70 \%$ & $85 \%$ \\
\hline & & & 8 & $50 \%$ & $90 \%$ \\
\hline & & & 10 & $45 \%$ & $95 \%$ \\
\hline & & & 15 & $45 \%$ & $80 \%$ \\
\hline & & & 20 & $40 \%$ & $85 \%$ \\
\hline & & & 25 & $0 \%$ & $75 \%$ \\
\hline & & & 30 & $0 \%$ & $75 \%$ \\
\hline & & & 35 & $0 \%$ & $60 \%$ \\
\hline & & & 40 & $0 \%$ & $50 \%$ \\
\hline \multicolumn{4}{|c|}{ Hasil Rata-Rata Akurasi } & $34 \%$ & $78 \%$ \\
\hline
\end{tabular}

Terlihat pada tabel bahwa hasil akurasi yang dihasilkan dengan menggunakan Euclidean Distance saat nilai $\mathrm{K}$ kecil akurasinya lebih besar dibandingakn dengan menggunakan metode NWKNN. Ketika K semakin besar dengan menggunakan CosSim hasil akurasi yang dihasilkan cenderung lebih baik walaupun hasil akurasi tersebut tidak stabil dibandingkan dengan Euclidean Distance yang bahkan menunjukkan akurasi $0 \%$ ketika $\mathrm{K}$ bernilai besar pada identifikasi jenis ADHD ini.

Oleh karena itu, untuk kasus identifikasi jenis ADHD menggunakan metode NWKNN ini, untuk menentukan kedekatan ketetanggaannya lebih baik menggunakanan perhitungan CosSim dengan ratarata hasil akurasi sebesar $78 \%$ dibanding Euiclidean Distance sebesar 34\%.

3.6 Pengujian dan Analisis Pengaruh Variasi Nilai Data Uji dan Data Latih yang BerubahUbah terhadap Akurasi

Pengujian dilakukan pada data latih sejumlah 80 data dan data uji sejumlah 20 data yang diambil secara acak dan nilainya berubah-ubah dengan menggunakan nilai $K$ terbaik yakni $K=10$ dengan nilai eksponen 4. Hasil pengujian tersebut dapat dilihat pada Tabel 7 berikut ini.

Tabel 7. Perubahan nilai pada data uji dan data latih.

\begin{tabular}{|c|c|c|c|c|c|c|}
\hline $\begin{array}{c}\text { Pengujia } \\
\text { n Ke }\end{array}$ & $\begin{array}{c}\text { Dat } \\
\text { a } \\
\text { Uji }\end{array}$ & $\begin{array}{c}\text { Data } \\
\text { Lati } \\
\text { h }\end{array}$ & $\begin{array}{l}\text { Nila } \\
\text { i K }\end{array}$ & $\begin{array}{l}\text { Nila } \\
\text { i E }\end{array}$ & $\begin{array}{c}\text { Akurasi } \\
\text { (NWKN } \\
\text { N) }\end{array}$ & $\begin{array}{c}\text { Akura } \\
\text { si } \\
\text { (KNN) }\end{array}$ \\
\hline 1 & \multirow{5}{*}{20} & \multirow{5}{*}{80} & \multirow{5}{*}{10} & \multirow{5}{*}{4} & 95 & 95 \\
\hline 2 & & & & & 60 & 65 \\
\hline 3 & & & & & 60 & 60 \\
\hline 4 & & & & & 65 & 60 \\
\hline 5 & & & & & 50 & 50 \\
\hline
\end{tabular}

Berdasarkan Tabel 7 terlihat bahwa perubahan nilai pada data uji dan data latih sangat mempengaruhi hasil akurasi. Hal tersebut terjadi karena pemilihan data yang digunakan sebagai data latih maupun data uji sangat mempengaruhi dalam proses identifikasi ADHD.

\section{SIMPULAN}

Berdasarkan hasil pengujian dan analisis terhadap identifikasi jenis Attention Deficit Disorder Hyperactivity (ADHD) dengan menggunakan metode Neighbor Weighted K-Nearest Neighbor (NWKNN), dapat disimpulkan bahwa metode NWKNN dapat melakukan identifikasi jenis ADHD dengan hasil akurasi terbaik pada saat $K=10, E=4$ dan data latih sebanyak 80 data dengan hasil 95\%. Dan untuk menentukan kedekatan ketetanggaan menunjukkan bahwa metode NWKNN dengan menggunakan CosSim memberikan hasil rata-rata akurasi lebih baik dari pada metode NWKNN dengan menggunakan Euclidean Distance pada kasus identifikasi jenis ADHD.

\section{SARAN}

Saran yang dapat diberikan pada kelanjutan penelitian identifikasi jenis ADHD dengan menggunakan metode NWKNN, yakni pada penelitian ini data yang digunakan hanya 100 data dan bersifat tidak seimbang dengan 1 kriteria berupa 45 pernyataan gejala tentang ADHD dengan batasan usia pada anak usia dini maksimal 7 tahun, diharapkan untuk penelitian selanjutnya dapat 
meningkatkan hasil akurasi dengan menambah jumlah data yang digunakan serta menambah kriteria seperti pengaruh usia maupun hasil prestasi disekolah.

\section{DAFTAR PUSTAKA}

DAO, S. D. \& MARIAN, R. 2011. Optimisation of precedence-constrained production sequencing and scheduling using genetic algorithms. Proceedings of the International Multi Conference of Engineers and Computer Scientists, 16-18 March, Hong Kong.

GEN, M. \& CHENG, R. 2000. Genetic Algorithms and Engineering Optimization. John Wiley \& Sons, Inc., New York.

LILIANA, D. Y. \& MAHMUDY, W. F. 2006. Penerapan Algoritma Genetika pada Otomatisasi Penjadwalan Kuliah. Laporan Penelitian DPP/SPP. FMIPA Universitas Brawijaya, Malang.

MARIAN, R. M., LUONG, L. \& DAO, S. D. 2012. Hybrid genetic algorithm optimisation of distribution networks - a comparative study. Dalam: AO, S. I., CASTILLO, O. \& HUANG, X. (editor.) Intelligent Control and Innovative Computing. Springer, US.

PHANDEN, R. K., JAIN, A. \& VERMA, R. 2013. An approach for integration of process planning and scheduling. International Journal of Computer Integrated Manufacturing, 26(4), 284-302.

RIDOK, A. 2014. Peringkasan dokumen Bahasa Indonesia berbasis non-negative matrix factorization. Jurnal Teknologi Informasi dan Ilmu Komputer (JTIIK), 1(1), 39-44.

TALA, F. Z. 2003. A Study of Stemming Effects on Information Retrieval in Bahasa Indonesia. Ph.D. Thesis. Universiteit van Amsterdam.

WANG, L. 2007. Process planning and scheduling for distributed manufacturing. Springer, London.

WIBAWA, A. P., NAFALSKI, A. \& MAHMUDY, W. F. 2013. Javanese 'speech levels machine translation: improved parallel text alignment based on impossible pair limitation. IEEE International Conference on Computational Intelligence and Cybernetics, 3-4 December, Yogyakarta, Indonesia. 16-20. 